\title{
Rumah Gadang as a Symbolic Representation of Minangkabau Ethnic Identity
}

\author{
Elda Franzia, Yasraf Amir Piliang, and Acep Iwan Saidi
}

\begin{abstract}
Minangkabau is one of the ethnic groups in Indonesia. This ethnic group is usually known by rumah makan padang or traditional food stall with spicy and delicious food in it, or by the people's specific choice of earning their living such as being a seller or entrepreneurs. On the other hand, every ethnic group has a symbol or other visual identity use for their identification. Rumah Gadang, the traditional house of Minangkabau, is one of the symbolic representations of Minangkabau's self identity. The unique visual form of Rumah Gadang can be seen in many visual identities of Minangkabau's people in daily basis, such as for rumah makan padang's logo, stall's identity, corporate identity, or as a virtual identity and a profile picture in social network site such as Facebook. This phenomenon is becoming the visual language in Indonesia's culture. With this paper, I intend to analyze the visual form of Rumah Gadang as the symbolic representation of Minangkabau's ethnic identity. Focused on Rumah Gadang as a visual object, the analysis is using semiotic method. Based on Pierce's theory of semiotics, Rumah Gadang is becoming the icon of Minangkabau's ethnic group and becoming their ethnic identity. The result is the classification of Rumah Gadang as a symbolic representation of ethnic identity.
\end{abstract}

Index Terms-Identity, Minangkabau, representation, Rumah Gadang.

\section{INTRODUCTION}

Indonesia is a developing country struggle in a mainstream of globalization. Globalization tends to change and determine the direction of human culture in a modern ways. This form of modernization often minimizes the greatness of ethnic culture, and in a way is reducing the symbolic meaning of traditional culture from the ethnic group of the country.

Globalization produces different outcomes for identity. The cultural homogeneity promoted by global marketing could lead detachment of identity from community and place. Alternatively, it could also lead to resistance, which could strengthen and reaffirm some local identity to the emergence of new identity position.

Minangkabau as one of the main ethnic group in Indonesia is effected by the globalization itself. This ethnic group is known for its dynamic ethnic culture. Minangkabau people are used to travels around the country seeking for a better living, education, and experience. This tradition called rantau and it is a common activity for young people from ethnic of Minangkabau. Through the activity of merantau,

Manuscript received September 24, 2013; revised November 28, 2013

Elda Franzia, Yasraf Amir Piliang, and Acep Iwan Saidi are with the Faculty of Art and Design, University of Trisakti, Bandung Institute of Technology (ITB), Bandung 40132, Indonesia (e-mail: eldafranzia@ gmail.com,ya_piliang@yahoo.com, acepiwansaidi@fsrd.itb.ac.id). the people of Minangkabau bring their culture and tradition to their new land.

Tradition is always becoming the base of the Minangkabau culture. People whose travel always looking for their ethnic group's society. People need to be rooted to their culture. It constructs their identity. Therefore the traveler is still connected to their villages and clan, and the traveler is always find the way to go back home.

Identity related to the cultural characteristic of the ethnic group. Rumah gadang is the traditional house of Minangkabau ethnic people. The modernization and globalization have transferred the rumah gadang into the symbolic position of people's tradition. Rumah gadang now is mainly a symbolic house for the Minangkabau people. Many various form of rumah gadang can be seen throughout the cities. This paper focused on the visual form of the rumah gadang as the representation of Minangkabau ethnic identity which appeared in different form of visual language.

\section{STUDY OF THE THEORY}

\section{A. Ethnic Identity}

Identity is a definition of self and the representation of self in personal and social contexts. In personal context, identity is a person's persona, personality, and a self definition of biological and psychological aspects of a person. In social context, identity is a differentiation from another person, and a way of other person's perception of a self. Through identity, a self becomes subject of persona, and conveys specific messages of representation. Identity is marked out through symbols and by difference [1].

Identity is a language of differentiation. The difference between people is inherited but also formed in society. It is in nature and culture. Nature shaped a person's gender, race, ethnic, and the biological aspects, while culture shaped a person's behavior, lifestyle, and the psychological aspect.

A person's nature identity includes race and ethnicity. Ethnicity is both a physical fact and a cultural creation. It is a genetic inheritance that embodies itself physically, but also a sign with cultural meanings. It refers to a sense of group affiliation based on a distinct heritage or worldview as people. Ethnicity is a cultural concept centered on the sharing norms, values, beliefs, cultural symbols and practices. It is not only based on primordial ties or universal cultural characteristic possessed by a specific group but also formed through discursive practices. Ethnicity is formed by the way we speak about group identities and symbols that identify the constitute ethnicity [2]. Cultural conception of self-identities and social perception formed the cultural self identity. 


\section{B. Symbolic Representation}

Representation is the centered question of cultural studies. It is how the world is socially constructed and represented to in meaningful ways. The study of culture is the signifying practices of representation. It embedded in objects, images, or another certain materiality [3]. Therefore the representation is a signifying practice appeared to stand for or depict another object or practice in the real world. Representation is the constitutive of culture, meaning, and knowledge.

Symbolic representation uses a symbol or a sign whereby items stand in for or represents another. Signs are commonly organized into a sequence that generates meaning through the cultural conventions of their usage within a particular context Such arrangement is called cultural codes. Sign become naturalized codes. They are appearing in meaning and outcome of cultural habituation. The effect of this is to conceal the practices of cultural coding.

Every meaning requires a motif if it is to be visualized. Not all the objects have clear connotations in all cultures. A referent of a sign based on abstract entity which is cultural conventions [4]. Cultural conventions shaped the pattern of signification in communication basis.

The semiotic scheme from Charles Sanders Peirce consists of the sign, the interpretant, and the object. Signification is understood as involving all three in a complex interaction. The sign stands to somebody or something. It addresses somebody and creates in the mind of that person an equivalent or developed sign. That sign which it creates is the interpretant of the first sign. The sign stands for the object, in reference to the ground idea of the object.

Peirce's second triad explains the different kinds of signs which human consciousness can interpret and accommodate. The triad consists of icons, index, and symbols [5]. The iconic sign resembles its conceptual object in certain ways. An icon takes its identity from its imitation of the signified, and stands for itself. The most obvious icons are photographs, image, painting, sculpture, and also the artifact architectural form such as rumah gadang.

\section{Visual Language}

Visual language is a system of communication using visual as text to send the message to the target of communication. Visual often treat as a binary opposition to the verbal. In visual language, image is the main factor of communication. Seeing comes before words. The way we see things is affected by what we know or what we believe. What we see becomes a stimuli and it is an act of choice. We never look at just one thing, but the relation between things and ourselves. Seeing is an active activity, it is continually active, continually moving, continually holding things around itself, and constituting what is present to us as we are [6].

Vision is not just a physiological activity of human body. Imagination, purpose, and desire are contaminating the mechanical process of light in human's eye. Seeing is perception. An experience of vision is a cultural appropriation of modernity in society. Images are the representational realism.

To understand the image is a kind of literacy. Visual literacy could be construed as an adequate capacity to identify images and to parse them according to the ways they refer to the world. Visual literacy also identified with the capacity to remember images. Beyond that, the interpretation is leading toward the understanding of pictorial content, significance, and use of the image [7].

\section{MinAngKabau EThNic SElF IDENTITY}

Minangkabau is one of approximately 140 ethnic groups from more than 3000 islands in Indonesia. Located in West Sumatra, the area is surrounded by Merapi Mountain, Sago Mountain, and Singgalang Mountain. Therefore the land of Sumatra Barat is known for their productivity. Besides of their land's fertility, the people from Minangkabau have several unique traditions, such as merantau, matrilineal, and their belief to Islam religion [8].

Merantau is the activity to travel out of their village to search for a better life, education, and experience. It is not only done because of urbanization process in modern culture, but it already becoming a life tradition. Minangkabau males go throughout the Southeast Asia or beyond to seek fortune as merchants or become scholars.

Matrilineal refers to familial relationship that can be traced through a female and maternal ancestor. It is a cultural lineage. A person in Minangkabau ethnic group related to their mother's family clan or suku. Suku is a female lineage unit which inherited landholding and clan's treasure. These family groups are typically led by a penghulu (headman) who elected by groups of lineage leaders. A person's clan name is his/her mother's clan. Matrilineal is the opposite of patrilineal system which is more common in Islamic country. Therefore it is a unique tradition of Minangkabau ethnic group.

The Minangkabau are strongly Islamic, but also follow their ethnic tradition or adat. The relationship between Islam and cultural tradition is describes by the saying adat basandi syarak, syarak basandi Kitabullah. It means that the tradition is founded upon Islamic law, and the Islamic law is founded upon the Holy Qur'an.

The tradition and Islamic believe is blend in their living. It is not to be placed as an opposite, but it strengthens both. Scholars and penghulu (headman in cultural clan) had discuss and confirmed that the tradition and the Islamic believe are both leading the culture to the same direction. It is the base of the ethnic identity and tradition.

\section{Rumah Gadang in Minangkabau Culture}

Rumah gadang means big house. It is a large rectangular house formed of rumah bagonjong, the spired roof house which is the traditional house of Minangkabau. The architecture, construction, internal and external decoration, and the function of the house reflect the culture and values of the Minangkabau. A rumah gadang serves as residence, a hall for family meetings, and for ceremonial activities. It is owned by the woman of the family who live there, and the ownership is passed from mother to daughter.

Rumah gadang as in Fig. 1 has dramatic curved roof structure with multiple gables and upsweeping ridges, 
formed like the horns of buffalo. The communal house is a long rectangular in plan. They normally have three-tiered projections, each with varying floor levels. The house is largely constructed of wood, with combination of bamboo and pattern. The roof made of palm fiber.

Some symbolism of the house related to the relation to the God and nature. The gonjong roof reaching to the God and the dindiang tapi (side wall) which is traditionally made of plaited strips of bamboo symbolizing the strength and utility of community which formed when individual Minangkabau become part of the larger community instead of standing alone.

The form that resembles the buffalo horn is often associated with stories Tambo Minangkabau Alam, the story of victory in the event of war between Minang people and the Javanese. To avoid the war, it negotiated to the buffalo fight. The Minang's buffalo finally win, and it also becomes the history of the name Minangkabau. Minang or menang means win and kabau or kerbau means buffalo.

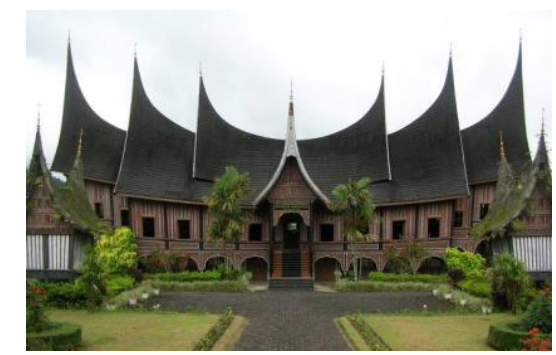

Fig. 1. Rumah Gadang.

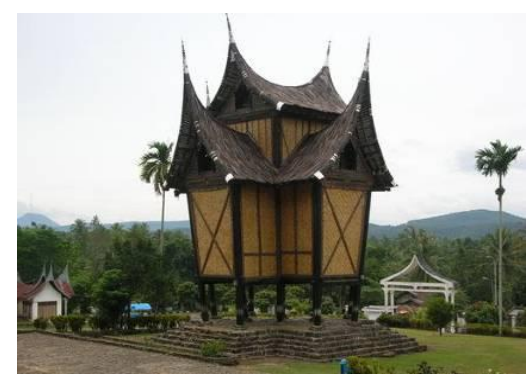

Fig. 2. Rangkiang.

Interior of rumah gadang is dominated by open rooms except the bedrooms. The rooms usually in odd number depend on the family number. Rangkiang (rice barn) as it shows in Fig. 2, usually put on the front yard of the house, on the left side and the right sight. Rangkiang ideally accompany a rumah gadang, with each having different name and function. The rangkiang also has a curved roof structure like a buffalo horn form, but in a smaller size. On the both wings of the main house is the anjuang, which is the raised floor to permit elevated seating of clan leads during the ceremonial events.

The rumah gadang traditionally have carved wooden motifs in the wooden walls, pillars, and ceilings. The motifs reflect and symbolize the culture. The motifs consist of floral designs based on a simple underlying geometric structure. These motifs also appear in woven textile (songket), embroidery, and other crafts. The colors derived from Chinese culture. Traditionally, the motif do not show animals on human in realistic form, because of the basis tradition is Islamic believe.

\section{RUMAH GADANG AS A SYMBOLIC REPRESENTATION OF MINANGKABAU ETHNIC SELF IDENTITY}

\section{A. Modern Building}

The dramatic curved roof structure that formed like the horns of buffalo is often use in modern building. The shape and contour of the roof give the ethnic identity of Minangkabau.

The Minangkabau traditional council hall, known as balai adat appears similar to a rumah gadang. This type of building is used by clan leaders as a meeting place. In West Sumatera some modern government and commercial building have adopted elements of rumah gadang style.

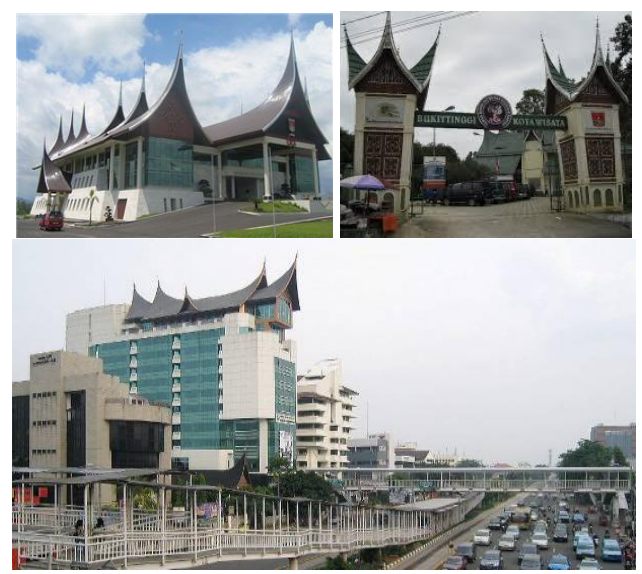

Fig. 3. Modern architectural.

Fig. 3 show the various kind of modern architectural in big cities using the shape and form of the roof from the traditional house. The Balaikota of Bukittinggi, the gate of Bukittinggi, and the Balairung Hotel in Jakarta, show the adaptation of traditional architecture in modern architecture. The adaptation is done basically in structure and construction and the function of the modern building. The size and form of bagonjong roof depend on the building structure and the landscape. The pattern and motif for aesthetic reasons also minimize, and the focus is the function and the cultural identity representation.

\section{B. Restaurant and Food Stall}

Culinary is one of the famous traditions of Minangkabau ethnic culture. Rumah makan Padang or Minangkabau food stall spread out in cities of Indonesia, even through South East Asia. The activity of merantau has spread out Minangkabau ethnic culture including the culinary ways, taste, and practice. The Minangkabau's people staple food is rice, and the spiciness is the characteristic of Minangkabau food. Traditional food of Minangkabau is famous for its rich taste of coconut milk and spicy chilli such as rendang, balado, and gulai. Because Minangkabau tradition and culture based on Islamic believes, the cuisine follows halal dietary law.

Food has a central role in the Minangkabau ceremonies which honor religious and life cycle rites. A certain kind of food often symbolizes a cycle of life such as wedding. It is also related to the Islamic festive such as Idul Fitri and Ramadhan. But in daily life the Minangkabau food are just it sell in rumah makan padang or traditional food stall like sate padang.

Fig. 4 show the form of traditional roof from rumah gadang use in a restaurant façade and in the street food stall. 
The façade is the face of a building, and give the identity impact beside the aesthetic and functional aspect of the building. The single form of swing roof is related to the form of rangkiang roof. It symbolizes the function of providing rice and food for the people.

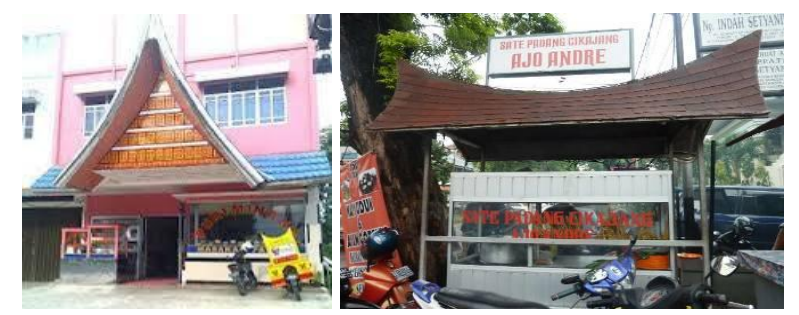

Fig. 4. Minangkabau traditional food-stall.

In the smaller building such as traditional food stall, the form of traditional roof and the aesthetic patterns of traditional house is being modified. The multiple gables and upsweeping ridges are not compatible for the small building. It is a common situation in the urban environment. Therefore only the front contour of the rumah gadang is adopted to relate to urban culture and to give the identity of Minangkabau culture in the building.

\section{Corporate Identity and Event Logo}

Logo is a graphic mark commonly used by commercial enterprises, organizations, and event to promote and gain public recognition. Brands use logos to impress values, functions, and hierarchies to the people. Logos are either contain graphic, symbols, icons, or composition of the name of organization. Visual icons communicate basically and directly. Logo is conveys the message of identity.

The form and contour of bagonjong roof in traditional house of Minangkabau appear in many corporate and event logo which related to West Sumatera or the culture of Minangkabau. To appear and use in a logo, rumah gadang is modified into stylistic and iconic form. Simplification is pivotal to logo design. The icon of rumah gadang combine with other symbols depends on the main purpose of the logo. Colors and symbols are used and become the main aspect of logo design to create brand awareness.

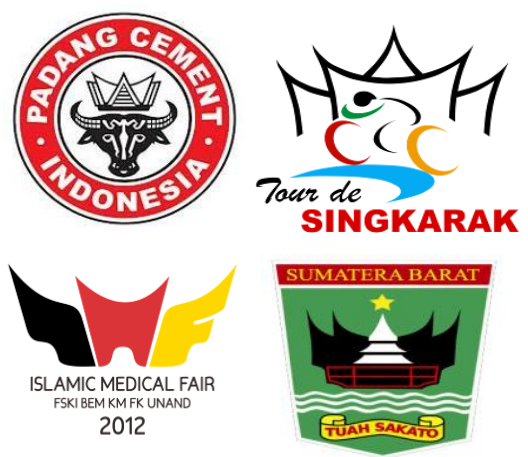

Fig. 5. Corporate and event logo.

Colors give identity of cultural and the connotation of cultural meaning. The colors of Minangkabau ethnic group is red, black, and yellow. These colors appear in many cultural artifacts such as rumah gadang's motif and traditional dresses. Logos in Fig. 5 are using those colors to give the cultural identity of Minangkabau other than commercial representation of the brand.

\section{Food Stall Identity}

Logo for food stall identity is quite different from corporate identity and event logo. The name of the restaurant is the main aspect of the logo. The image or iconic symbol using for the logo often combine with the initial or the name of the restaurant.

The form of bagonjong roof is becoming the collective cultural code in food stall identity. The appearance of Minangkabau traditional food stall is related to the matrilineal and other cultural tradition such as culinary and travel activity merantau. In Minangkabau tradition, gonjong is a form of femininity (bundo kanduang) [9]. The form of bagonjong roof use by the male traveler is symbolizes the loyalty of the traveler to their clan and family.

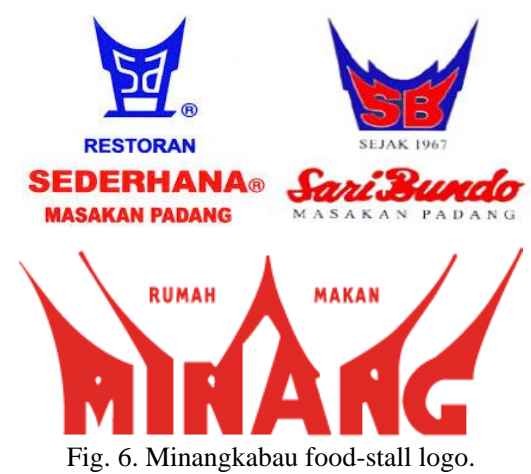

Fig. 6 show the form and contour of rumah gadang that appear in traditional Minangkabau food stall logo. Those logos have the form of curved roof structure formed like the horns of buffalo in a simplicity style. The form of the bagonjong is the main icon in the food stall logo, modified from rumah gadang or rangkiang. It gives the symbolic representation of Minangkabau cultural and tradition beside of the commercial need of the logo.

The name is using a specific characteristic of typography which also often modified to the form of the roof. The colors use to give the identity of the food stall, and the typography enhances the characteristic of Minangkabau culture and identity. The logo gives the cultural identity of Minangkabau other than commercial representation of the food stall.

\section{E. Virtual Identity}

Virtual identity is an identity constructed in cyberspace. Cyberspace is an information space exists within a computer, internet, and the World Wide Web. In cyberspace, a person becomes exist through $\log$ in and $\log$ out activities in a site. The internet is another element of the computer culture that has contributed to thinking about identity as multiplicity. Therefore the identity in internet is dynamic and fluid.

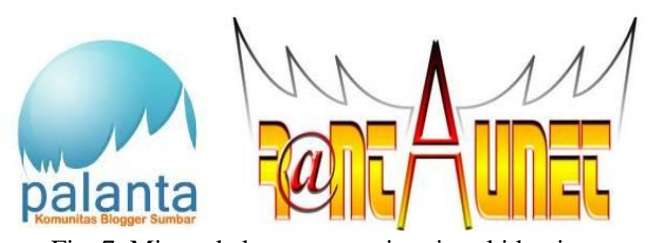

Fig. 7. Minangkabau community virtual identity.

Fig. 7 shows the identity of Minangkabau community in cyberspace. The identity is the logo of the community. It also 
has the specific characteristic of rumah gadang in it. The contour is simplified and the main object is the name of the community. As the logo of an electronic media, simplicity also the main aspect of the logo design. The form of the roof is reduces to the minimalist style, and the multiple curved reaching to above is the key characteristic of Minangkabau ethnic identity.

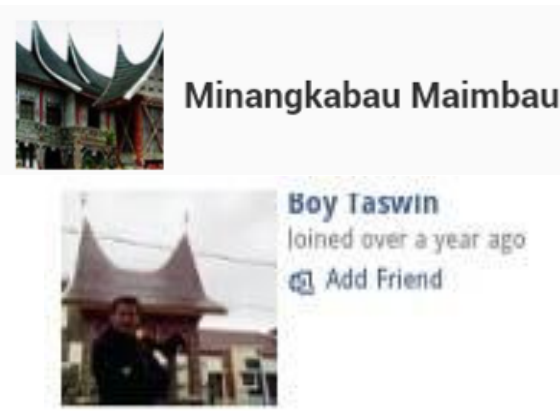

Fig. 8. Minangkabau profile picture in Facebook.

Fig. 8 show the profile picture of Minangkabau people in the social network site Facebook. The profile picture is one of many form of virtual identity. It is the communicative expression in the context of social network sites. In this context, online communication occurs through speech and image. Profile picture is a representation of an account or a person behind it. From the perspective of communication theory, the profile picture can be defined as a communicative act [10]. It conveys the message of the person's identity, the identification of a personal entity, and the surrogate for presence in cyberspace.

Photography is a means of self-expression and the manifestation of the individualized "I". It depicts reality that already exists [11]. Therefore a photographic image has relation to both of similarity and adjacency to its object. Photographs are in certain respects exactly like the object they represent. It has resemblance to the nature of the object and has physical connection to the object. The photographic image of rumah gadang conveys the message about the account's cultural identity. Rumah gadang becomes the symbolic representation of the person's ethnic background.

\section{CONCLUSION}

Rumah gadang has a unique form and can be simplified in graphic visual contour. The multiple layered roofs that are the main characteristic of bagonjong roof appeared in many different forms of modern architecture, traditional food stall, corporate $\log o$ and identity, and as virtual identity in cyberspace. There are in different dimension, different elements, and all perform as a symbolic representation as in Table I below.

Being used to identify the ethnic group of Minangkabau, rumah gadang is becoming a cultural code and related to the real tradition and culture of Minangkabau people. It represents the history of Minangkabau and the femininity of bundo kanduang.

In conclusion, the modern architecture that has a certain characteristic of bagonjong roof is the iconic symbol of rumah gadang traditional house. On the other hand, the logo and the pictures show the form and contour of rumah gadang, also the iconic symbol of rumah gadang. They all use to convey the message of ethnic identity of Minangkabau and relation to the land of West Sumatera. Therefore, rumah gadang becomes the symbolic representation of Minangkabau ethnic identity.

TABLE I: THE ClASSIFICATION OF RUMAH GADANG AS A SYMBOLIC REPRESENTATION OF ETHNIC IDENTITY

\begin{tabular}{|c|c|c|c|}
\hline Form & Dimension & Elements & $\begin{array}{l}\text { Symbolic } \\
\text { Representation }\end{array}$ \\
\hline Modern Building & $3 \mathrm{D}$ & $\begin{array}{l}\text { Architectural } \\
\text { Landscape } \\
\text { Form }\end{array}$ & $\begin{array}{l}\text { Modernity } \\
\text { Ethnic Identity } \\
\text { Minangkabau }\end{array}$ \\
\hline Food Stall & $3 \mathrm{D}$ & $\begin{array}{l}\text { Architectural } \\
\text { Form } \\
\text { Color }\end{array}$ & $\begin{array}{l}\text { Urban Culture } \\
\text { Ethnic Identity } \\
\text { Minangkabau }\end{array}$ \\
\hline Logo & $2 \mathrm{D}$ & $\begin{array}{l}\text { Form } \\
\text { Type } \\
\text { Color }\end{array}$ & $\begin{array}{l}\text { Commercial } \\
\text { Ethnic Identity } \\
\text { Minangkabau }\end{array}$ \\
\hline Food Stall Logo & $2 \mathrm{D}$ & $\begin{array}{l}\text { Form } \\
\text { Type } \\
\text { Color }\end{array}$ & $\begin{array}{l}\text { Commercial } \\
\text { Ethnic Identity } \\
\text { Minangkabau }\end{array}$ \\
\hline Virtual Identity & $2 \mathrm{D}$ & $\begin{array}{l}\text { Form } \\
\text { Type } \\
\text { Color }\end{array}$ & $\begin{array}{l}\text { Community } \\
\text { Ethnic Identity } \\
\text { Minangkabau }\end{array}$ \\
\hline Profile Picture & $2 \mathrm{D}$ & $\begin{array}{l}\text { Form } \\
\text { Image } \\
\text { Color }\end{array}$ & $\begin{array}{l}\text { Personal/Group } \\
\text { Ethnic Identity } \\
\text { Minangkabau }\end{array}$ \\
\hline
\end{tabular}

\section{REFERENCES}

[1] K. Woodward, Identity and Difference; London: Sage Publication, 2009 , pp. 9.

[2] C. Barker, Cultural Studies, Theory and Practice, London: Sage Publication, pp. 256.

[3] C. Barker, Cultural Studies, Theory and Practice, London: Sage Publication, pp. 8.

[4] U. Eco, A Theory of Semiotics, Yogyakarta: Kreasi Wacana, pp.96.

[5] K. Silverman, The Subject of Semiotics; New York: Oxford University Press, 1983, pp. 14-19.

[6] J. Berger, Ways of Seeing, London: Penguin Books, 1972, pp. 7-9.

[7] J. Elkins, Visual Studies, London: Routledge, 2003, pp. 137.

[8] T. Kato, Matriliny and Migration; Evolving Minangkabau Tradition in Indonesia, Jakarta: Balai Pustaka, 2005, pp. 1-9.

[9] R. Trinanda, "The Gonjong Pattern in padang food stall merck in visual communication design," Semiotics Analysis in Gonjong Pattern for Padang Food Stall Merck, M. Sn. thesis, Institut Seni Indonesia, Yogyakarta, Indonesia, 2013.

[10] J. Astheimer, K. N. Braun, and A. Schmidt, "My Face: Portrait Photography on the Social Web," in The Visual Worlds of Social Network Sites, U. P. Authenrieth, K. Neumann-Braun, Eds. Deutch: Nomos Verlagsgesellschaft, 2011, pp. 17.

[11] S. Sontag, On Photography, New York: Picador, Farrar, Straus, and Giroux, 1977, pp. 119.

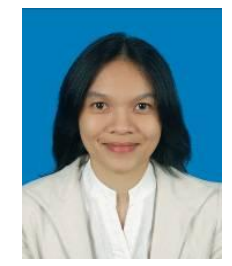

Elda Franzia was born in Paris, on May 7, 1973. She was with Faculty of Art and Design, University of Trisakti, Jakarta, Indonesia in 1997. Major field of study is visual communication design; and received Master of Design, from University of Trisakti, Jakarta, Indonesia in 2009. Major field of study is design; and Student of Doctoral Program, Faculty of Art and Design, Bandung Institute of Technology (ITB), Bandung, Indonesia. Currently as a lecturer staff at Faculty of Art and Design, University of Trisakti, Jakarta, Indonesia. 


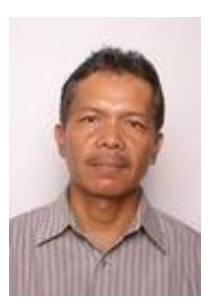

Yasraf Amir Piliang was born in Maninjau, West Sumatera, on September 30, 1956. He is with faculty of art and design, Bandung Institute of Technology (ITB) Bandung, Indonesia 1984; Doctoral Program, Faculty of Art and Design, Bandung Institute of Technology (ITB), Bandung, Indonesia 2007. Currently as a lecturer staff at Doctoral Program, Faculty of Art and Design, Bandung Institute of Technology (ITB), Bandung, Indonesia. Previous publication: Dunia Yang Dilipat: Tamasya Melampaui Batas-batas Realitas (Bandung: Matahari, 2011); Semiotika dan Hipersemiotika: Kode, Gaya dan Matinya Makna, (Bandung: Jalasutra, 2011); Multiplisitas dan Diferensi: Redefinisi Desain, Teknologi, dan Humanitas, (Bandung: Jalasutra, 2007)

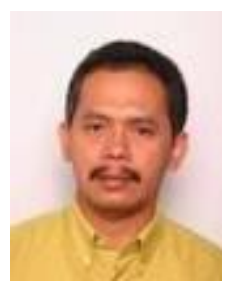

Acep Iwan Saidi was born in Bogor, West Java, on March 9, 1969. He is with faculty of literature, University of Padjajaran, Bandung, Indonesia 1995; receives Master of Humaniora, from Faculty of Cultural Science, University of Indonesia, Indonesia 2002, and then Doctoral Program, Faculty of Art and Design, Bandung Institute of Technology (ITB), Bandung, Indonesia 2007. Currently as a lecturer staff at Doctoral Program, Faculty of Art and Design, Bandung Institute of Technology (ITB), Bandung, Indonesia. Previous publication: Mendesain Penjara (Yogyakarta: Isacbook, 2010); Mengapa Saya Bukan Aku (Yogyakarta: Isacbook, 2008); Narasi Simbolik Seni Rupa Kontemporer (Yogyakarta: Isacbook, 2008) 